\title{
Do Indonesian Muslims Have Intention to Participate on Cash Waqf Through Fintech?
}

\author{
Farokhah Muzayinatun Niswah ${ }^{1}$, Lu'liyatul Mutmainah ${ }^{2}$, Faizatu Almas \\ Hadyantari $^{3}$, Nurwahidin ${ }^{4}$, Nurul Huda ${ }^{5}$ \\ \{faroh.blue@gmail.com¹, sakinah.lym@gmail.com², fahadyantari@gmail.com³, \\ nurwahidin@ui.ac.id ${ }^{4}$,pakhuda@yahoo.com $\left.{ }^{5}\right\}$ \\ ${ }^{1,2,3,4}$ School of Strategic and Global Studies, Universitas Indonesia, Indonesia, \\ ${ }^{5}$ Universitas YARSI, Indonesia
}

\begin{abstract}
The use of financial technology (fintech) gives a significant impact on people's daily activities in this digital era. The growth numbers of commercial fintech are also followed up by the growth of fintech for charity purposes. This study aims to analyze the intention of Indonesian Muslims towards cash waqf participation through fintech. An online survey is used in this study that consists of 129 Indonesian Muslims. Technology Acceptance Model (TAM) and Theory of Planned Behavior (TPB) variables used in this research. Data analyzed by Partial Least Square-Structural Equation Modeling (PLSSEM). The results show that Perceived Usefulness (PU) and Perceived Ease of Use (PEU) statistically have a significant effect on Attitude towards Usage (ATU). PU, ATU, and PEU have a significant effect on Behavioral Intention (BI). Perceived Behavioral Control (PBC), PU, and Subjective Norm (SN) have no significant effect on BI. Fintech should give better performance to collect waqf funds.
\end{abstract}

Keywords: Fintech, Cash waqf, Intention, Muslim

\section{Introduction}

The use of financial technology (fintech) gives a significant impact on people's daily activities in this digital era. A report from Aftech in 2018 showed that grow of fintech reachs up to 250 fintech companies in Indonesia, which dominated by peer-to-peer lending platforms $(40 \%)$ and payments (34\%). The segmentation of private investments from 2015 to 2018 in Islamic Fintech is about US\$12.6 million [1].

Muslims have practiced the important role of social finance for a long time ago. Islamic social finance such as waqf is one of the financial instruments that can contribute to wealth nation by evidence (Waqf from Umar bin Khattab, Waqf Al Azhar in Egypt, Sukuk Linked Waqf, etc.). Waqf can be defined as retained property that is specific, owned whose ownership is transferable and it can be benefitted from while the property itself, and is an ongoing charity [2]. Waqf also has some of categorizing such as perpetual waqf assets like land and buildings, productive waqf that can be generated from cash waqf, family waqf that given and managed by family, and others.

Waqf in this contemporary world also can be collected through technology. The combination between fintech company and waqf institution to break the gap between potential and realization of waqf assets. Indonesia is one of the biggest Muslim population in the world; 
the amount is about $88 \%$ [3]. This significant amount also supports Indonesia to have a big potential of waqf assets that involve waqf land and waqf money that are about 4.359.443.170 meter squares of land and 77 trillion rupiahs [4] [5]. This statement also supported by the report of World Giving Index Score, which announced that Indonesia is the most philanthropist people in the world [6]. Unfortunately, this potential is a lack of real waqf fundraising that reported to the government.

Surprisingly, Indonesia is a country that has significant internet penetration. Data from We Are Social [7] explained that the Indonesian population that consists of 56\% (internet) and 48\% (mobile) active social media user. Indonesia also estimated to have 50 million new internet users from 2015-2020 [8]. Therefore, fintech can grow up rapidly in this country.

The growth numbers of commercial fintech are also followed up by the growth of fintech for charity purposes. The platforms that implement this purpose are Ammana (shariah peer-topeer lending platform), LinkAja (payment platform that has a relationship with 40 foundations), Gopay (Go-give program), and others. Ammana gives more advantage to give waqf through that platform. After that, Ammana will distribute it to the waqf institution that synergizes with the company. Some of the waqf institutions also adopt technology to enhance their fundraising performance by developed well-managed websites, applications (apps), and marketing through fintech (kitabisa.com), for example, Wakaf DT, Gelombang Wakaf, Wakaf MUI, etc. Fintech can reduce necessary functions slowly with something better, faster, and cheaper [9].

The purpose of this study is to examine the effect of the Technology Acceptance Model (TAM) and the Theory of Planned Behavior (TPB) variables on Muslim intention to do cash waqf through fintech. This research also tries to explore the awareness of Muslims in Indonesia about the waqf platform.

\section{Literature Review}

\subsection{Theory}

\subsubsection{Financial Technology}

Financial Technology (Fintech) is a general term to refer to a technological innovation in the field of financial services. Fintech used in explaining the picture of change about how businesses try to improve the process, delivery, and use of financial services [10]. Digital-based financial services that have developed in Indonesia include payment channel systems, digital banking, online digital insurance, peer-peer peer lending (P2P), and crowdfunding. Some of the advantages of fintech include standardized and low-cost financial services, low-risk regulation of financial services [11]. Fintech regulated by Bank Indonesia on number 19/12/PBI/2017 concerning Implementation of Financial Technology which explains that the organization of financial activities can be in the form of payment systems, market support, investment management and risk management, loans, financing, and capital provision [10].

\subsubsection{Cash Waqf}

Waqf have played an essential role in the regulation of social goods, public goods, commercials, religious services as well as developing various development projects for Muslim communities [13] [14] [15]. The concept of waqf is indeed not explained concretely in Islam, 
but the recommendation to continue to do is to remember that waqf is a part of the charity that is continual use and enduring usefulness. The Messenger of Allah said, from Abu Hurairah RA, "If the child of Adam (human) dies, then the reward of all his deeds will be cut, except for three types of charity, namely: almsgiving jariyyah (waqf), useful knowledge and pious children who always suffer their parents". The hadith explains that the alms of jariyyah in the hadith are the same as waqf [15].

Cash Waqf is a form of waqf with the object of the object in the way of money. Cash Waqf is regulated in Law number 41 year of 2004 about Waqf in Article no.6 concerning the purpose of waqf property. Cash Waqf can be defined by giving a sum of money from assets owned and endowing it based on an agreement with the nazir. The results of the management of cash waqf are used for the benefit and development of the people [16]. There are four reasons for the use of cash waqf, the amount of cash waqf varies so there are no specific restrictions related to the amount, being one financing alternative in the productivity of not neglected assets or neglected assets so that it can be managed into productive lands, becoming one aid alternative on solving the problem of funding difficulties in Islamic education, and encourage Muslims to be independent because they do not have to depend on the state budget [17].

\subsubsection{Theory of Planned Behavior (TPB) and Theory of Acceptance Model (TAM)}

Theory of Planned Behavior (TPB) is a conceptual framework that aims to deal with the complexity of human social behavior and is used to explain individual behavior patterns in decision making that has 3 independent variables determine the Behavioral Intention (Subjective Norm, Perceived Behavioral Control, and Attitude Towards Usage) [18] [19]. While Theory of Acceptance Model (TAM) is a method for analyzing individual acceptance behavior in information technology and information systems [20]. This model was developed by two factors, including Perceived Ease of Use and Perceived Usefulness [21].

Subjective Norm (SN) is a social pressure that is a feeling to contribute cash waqf through fintech or not. Perceived Behavioral Control (PBC) is ease or difficulty that someone feels in providing cash waqf through fintech and assumes to reflect their past experiences and obstacles that they anticipated. Perceived Usefulness (PU) is the extent to which someone believes that using a fintech will be able to improve their work performance in contributing cash waqf. Perceived Ease of Use (PEU) is a measurement of the extent to which someone believes that using fintech will be free of effort in contributing cash waqf. Attitude Towards Usage (ATU) is the scale to which someone evaluates the contribution of cash waqf through fintech is liked or disliked. Behavioral Intention (BI) is an indication of how hard someone wants to try, how much effort to plan to contribute cash waqf through fintech and factors that influence someone to participate cash waqf through fintech.

\subsection{Previous Studies}

Previous studies that discussed fintech or waqf are dominated by only focusing on cash waqf intention. First, explored determinant factors that influence cash waqf intention [22] [23]. Second, explored the antecedents and consequences of Muslims attitude towards cash waqf participation [24]. Research that focuses on fintech usage delivered by Kim, Won-Jun, and Rusydiana [25] [26] [27]. A conceptual framework of Model Sharia Financial Technology that integrated start-up fintech and waqf funds [12]. This study suggested a model become the solution of financing start-up companies based on waqf funds. As far as this research conducted, there was no one literature that focuses on the intention of cash waqf participation through 
fintech. This research area has significant implementation to optimize the potential of cash waqf among Indonesian Muslims.

\section{Methodology}

Type of data used in this study are primary and secondary data. First, secondary data are collected from some literature, such as journals, books, and information from websites that matched our topic research. Then, primary data collected from respondents through online questionnaires. While the technique to take a sample of the study is the Convenience Sampling Method. The criteria of the sample are Indonesian Muslims. The question items are based on theory and previous researches that are matched with research topic. Partial Least SquareStructural Equation Modeling (PLS-SEM) used to analyze the questionnaire data. PLS-SEM can be used with a small sample size, even though the model is very complex [28]. The minimum sample size used in PLS-SEM is ten times the maximum number of independent variables in the outer and inner models [29]. It can also be said that the minimum sample of research is ten times the largest number of formative indicators in each construct in the outer model (the number of indicators for each formative construct) or ten times the number of the largest structural paths directed at a particular latent construction in the inner model. There are seven (7) structural paths (path arrows) in this research, so the minimum size of the sample is 7 $\mathrm{x} 10=70$ samples. There are 129 respondents have met the criteria and used as a sample in this study. Questionnaire made using Five-point Likert scales ranging from "strongly disagree" (1) to "strongly agree" (5). PLS-SEM used by the help of SmartPLS 3 application to proceed the questionnaire data. The model of this research can be seen in Figure 1.

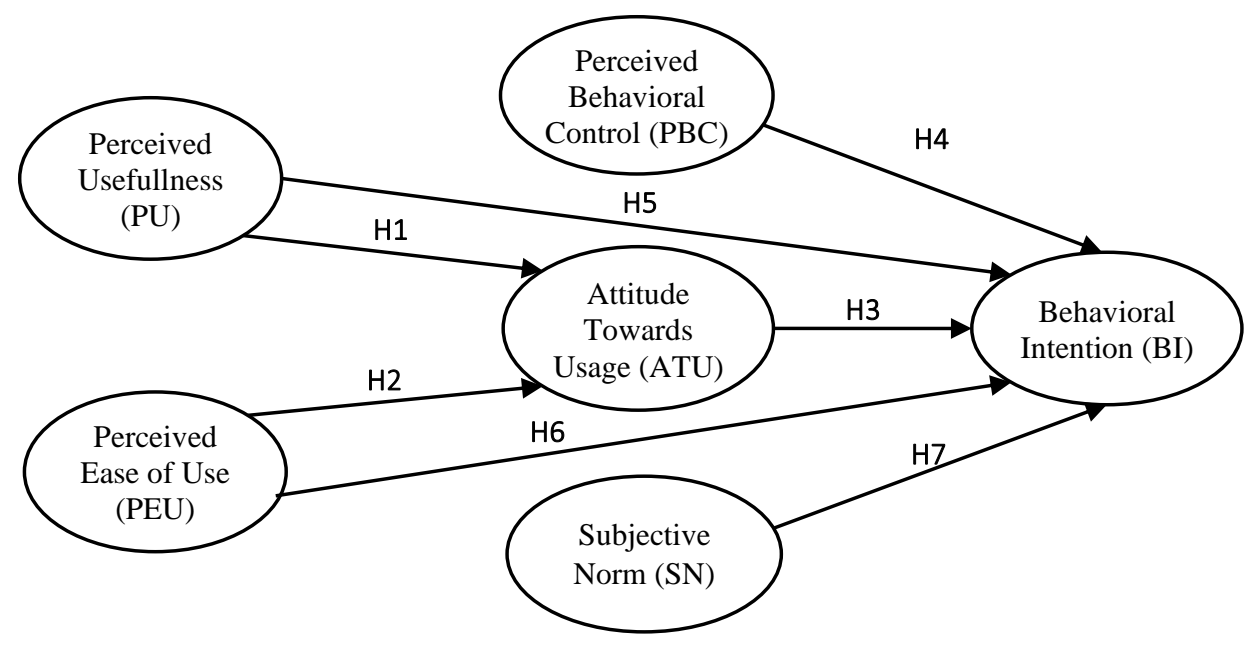

Fig. 1. Research Framework

Figure 1 describes about the hypotheses of the study. There are six (6) latent variables and seven (7) hypotheses, they are: 
$\mathrm{H}_{1}$ : Perceived Usefulness (PU) substantially has a positive effect on Attitude Towards Usage (ATU) of waqf fintech

$\mathrm{H}_{2}$ : Perceived Ease of Use (PEU) substantially has a positive effect on Attitude Towards Usage (ATU) of waqf fintech

$\mathrm{H}_{3}$ : Attitude Towards Usage (ATU) substantially has a positive effect on Behavioral Intention (BI) of using waqf fintech

$\mathrm{H}_{4}$ : Perceived Behavioral Control (PBC) substantially has a positive effect on Behavioral Intention (BI) of using waqf fintech

$\mathrm{H}_{5}$ : Perceived Usefulness (PU) substantially has a positive effect on Behavioral Intention (BI) of using waqf fintech

$\mathrm{H}_{6}$ : Perceived Ease of Use (PEU) substantially has a positive effect on Behavioral Intention (BI) of using waqf fintech

$\mathrm{H}_{7}$ : Subjective Norm (SN) substantially has a positive effect on Behavioral Intention (BI) of using waqf fintech.

\section{Results and Analysis}

\subsection{Results}

\subsubsection{Demographic Information}

The characteristic of respondents in this study shown in Table 1. The background of respondents can influence the way they answer the questionnaire and effect on the result of the research.

Table 1. Demographic Information of The Respondents

\begin{tabular}{llcc}
\hline Characteristic N=129 & Frequency & Percentage \\
\hline Gender & Description & 34 & $26 \%$ \\
Age & Female & 95 & $74 \%$ \\
& $19-23$ years old & 29 & $22 \%$ \\
& $24-29$ years old & 76 & $59 \%$ \\
& $30-34$ years old & 11 & $9 \%$ \\
& $35-39$ years old & 7 & $5 \%$ \\
\multirow{5}{*}{ Education } & 4 & $3 \%$ \\
& A0- 45 years old & 2 & $2 \%$ \\
& Seniove High School & 8 & $6 \%$ \\
& Undergraduate & 84 & $65 \%$ \\
& Postgraduate & 36 & $28 \%$ \\
& Doctoral & 1 & $1 \%$ \\
Occupation & Student & 48 & $37 \%$ \\
& Civil Servant & 10 & $8 \%$ \\
\hline
\end{tabular}




\begin{tabular}{llcc}
\hline Characteristic N=129 & & \\
Description & Frequency & Percentage \\
\hline \multirow{6}{*}{ Region } & Private Employee & 30 & $23 \%$ \\
& Entrepreneur & 3 & $2 \%$ \\
& Teacher/Lecturer & 14 & $11 \%$ \\
& Housewife/Unemployment & 8 & $6 \%$ \\
& Others & 16 & $12 \%$ \\
& Jabodetabek (Jakarta, & 56 & $43 \%$ \\
& Bogor, Depok, Tangerang, & & \\
& Bekasi) & & \\
& Outside Jabodetabek (but & 62 & $48 \%$ \\
& in Java) & & \\
& Not in Java & 11 & $9 \%$ \\
\hline
\end{tabular}

This study involved 129 respondents from Indonesian Muslims, with the majority in this study are female (74\%) with predominantly aged between $24-29$ years, about $59 \%$, and $95 \%$ of them are millennial's generation. Most of them have good background education, with $65 \%$ of respondents study at undergraduate level. These respondents also are dominated by students (37\%) and private employees (23\%). The respondents who live outside Jabodetabek area are the biggest with $48 \%$, and in Jabodetabek is $43 \%$.

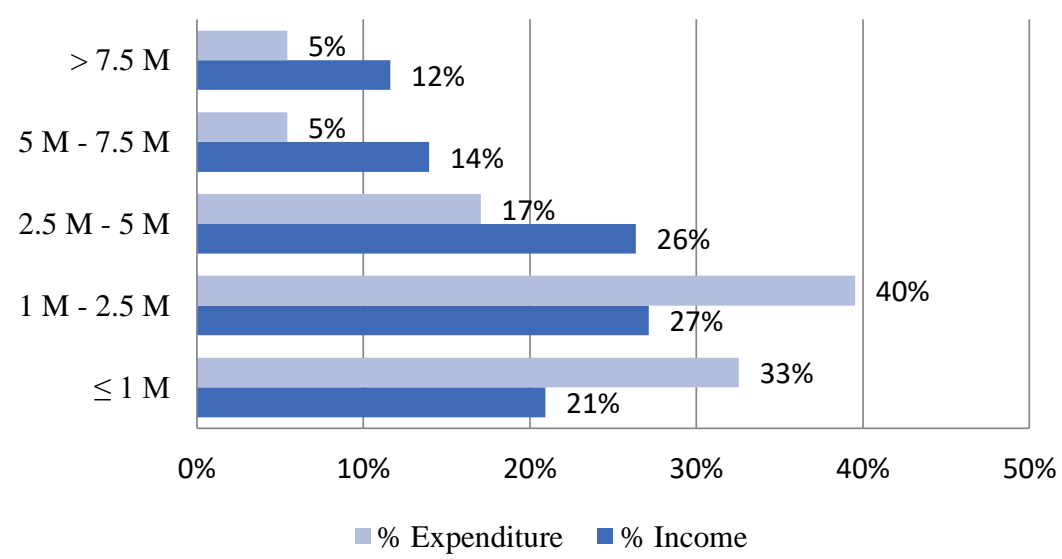

Fig. 2. Income and Expenditure Amount of Respondents

Based on Figure 2, 27\% of respondents have a monthly income between Rp1 million up to Rp2.5 million, and $26 \%$ of them earn between Rp2.5 million to Rp5 million. However, the 
expenditure of them is getting higher than income for the classification of less than Rp1 million and Rp1 million up to Rp2.5 million. This is an unpredictable condition in this study.

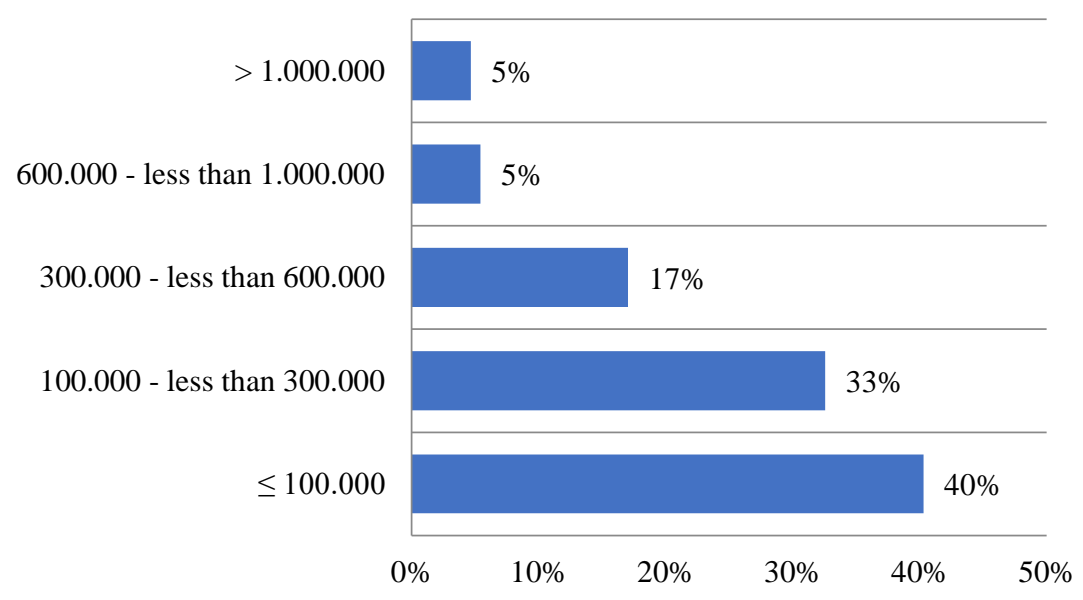

Fig. 3. Charity Amount of Respondents

According to Figure 3, most of the respondents give charity about less than Rp100.000 per month (40\%). Then, 33\% of them provide about Rp100.000 up to Rp300.000 and only $10 \%$ in total, respondents who give charity between Rp600.000 up to more than Rp1 million.

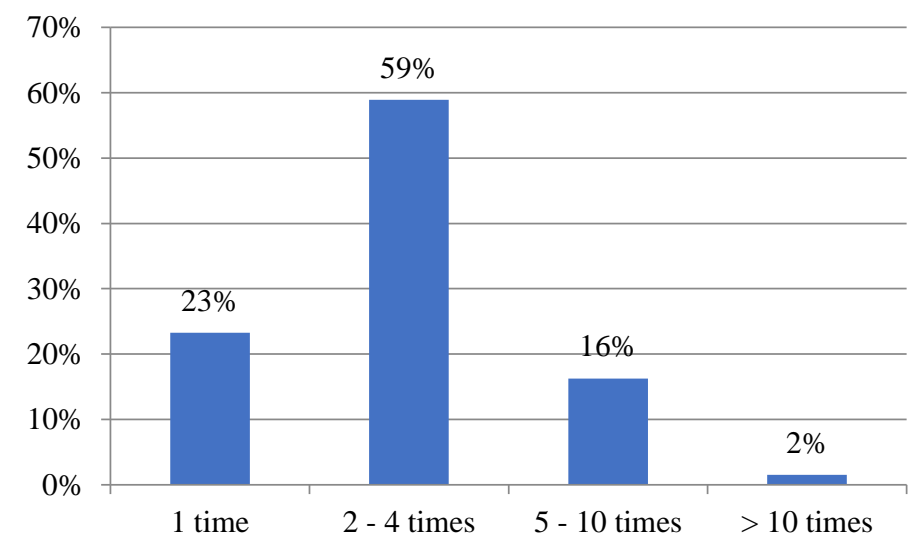

Fig. 4. Monthly Frequency of Giving Charity 
Based on the data on Figure 4, 59\% of respondents give charity (infaq/zakat/shadaqah/waqf) between 2-4 times a month and only $2 \%$ who give it more than ten (10) times per month.

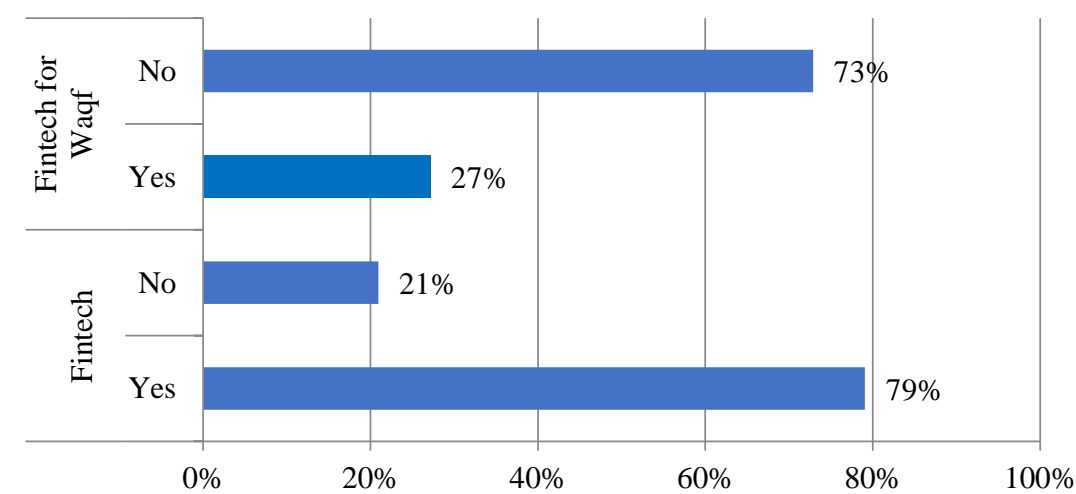

Fig. 5. Respondent Knowledge

According to Figure 5, $79 \%$ of respondents knew fintech. However, only $27 \%$ of them knew that fintech could be used for waqf. Although Indonesia has a big potential of cash waqf, people have lack of awareness and education about waqf [30] [31] [32]. Indonesia also has known as the high population that use internet in their daily activities with more than $50 \%$ of internet penetration [7].

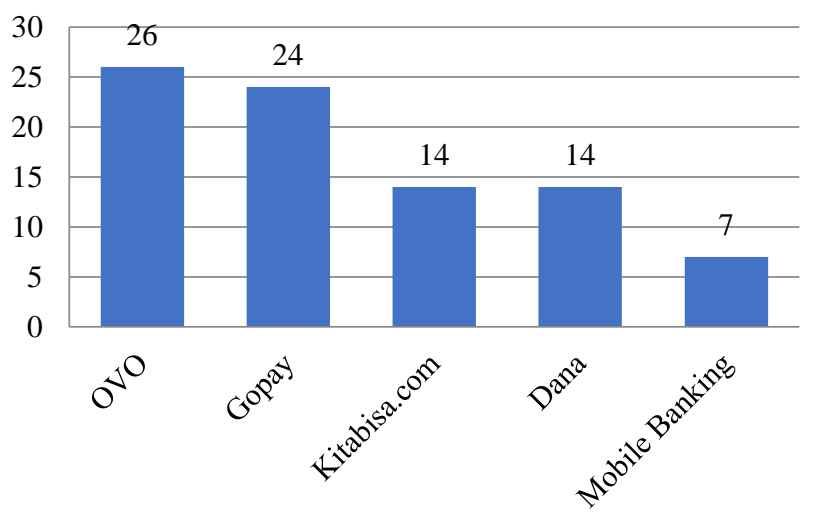

Fig. 6. Usage of Fintech Platform 
Figure 6 describes what platform of fintech that respondents already use. Based on the result, there is an area of more than 30 platforms mentioned by respondents. Top of five of the platforms used by respondents is OVO, Gopay, Kitabisa.com, Dana, and Mobile Banking. OVO is the most fintech that used, among others. Some of the respondents use more than one platform.

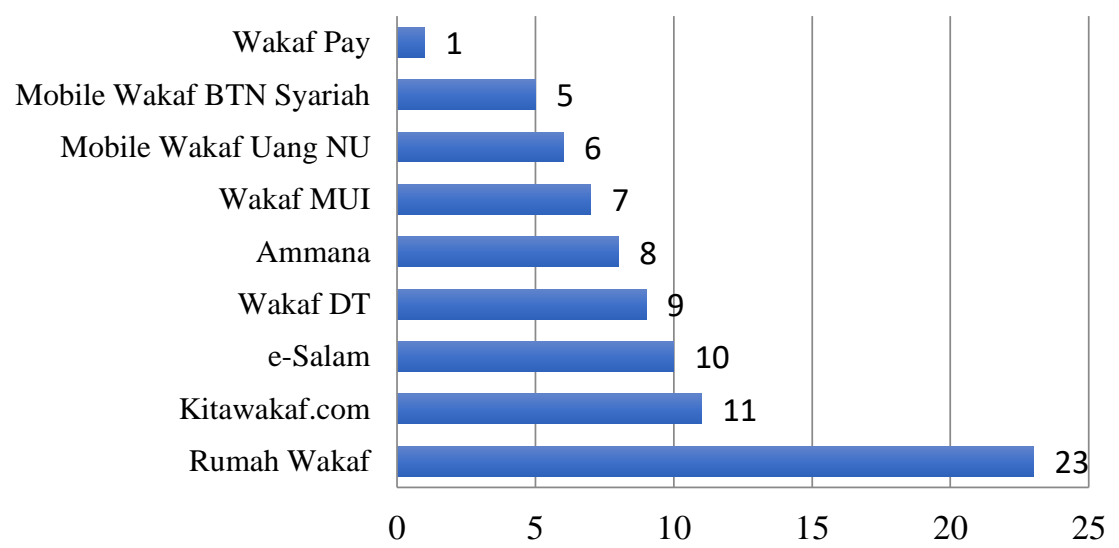

Fig. 7. Knowledge about Fintech Platform for Waqf

Based on Figure 7, even though many platforms of fintech in Indonesia, Indonesian Muslims only know a little bit about fintech that used for waqf payment. There are only ten platforms mentioned, and Rumah Wakaf is the best known by respondents. This finding supports previous researches that Indonesia has a lack of waqf understanding [30] [31] [32]. Integration of waqf and social crowdfunding can attract people to do waqf easily [33].

\subsubsection{Evaluation of Measurement Models, Evaluation of Structural Models and Hypothesis Test}

This section will explain the output of the running questionnaire data using PLS-SEM method and with the help of SmartPLS application.

Evaluation of Measurement Models (Outer Models). The first evaluation that must be done in PLS-SEM is the evaluation of measurement models or outer models. The model would passes the evaluation if it passed reliability and validity test. 
Table 2. Reliability and Validity Test

\begin{tabular}{|c|c|c|c|c|c|}
\hline Construct & Item & $\begin{array}{l}\text { Cronbach's } \\
\text { Alpha }\end{array}$ & $\begin{array}{l}\text { Composite } \\
\text { Reliability }\end{array}$ & $\begin{array}{l}\text { Outer } \\
\text { Loading }\end{array}$ & $\begin{array}{l}\text { Average } \\
\text { Variance } \\
\text { Extracted } \\
\text { (AVE) }\end{array}$ \\
\hline \multirow{6}{*}{ PU } & PU1 & \multirow{6}{*}{0,930} & \multirow{6}{*}{0,945} & 0,895 & \multirow{6}{*}{0.742} \\
\hline & PU2 & & & 0,887 & \\
\hline & PU3 & & & 0,889 & \\
\hline & PU4 & & & 0,761 & \\
\hline & PU5 & & & 0,864 & \\
\hline & PU6 & & & 0,867 & \\
\hline \multirow{6}{*}{ PEU } & PEU1 & \multirow{6}{*}{0,941} & \multirow{6}{*}{0,953} & 0,875 & \multirow{6}{*}{0.773} \\
\hline & PEU2 & & & 0,915 & \\
\hline & PEU3 & & & 0,912 & \\
\hline & PEU4 & & & 0,910 & \\
\hline & PEU5 & & & 0,787 & \\
\hline & PEU6 & & & 0,868 & \\
\hline \multirow{5}{*}{ ATU } & ATU1 & \multirow{5}{*}{0,915} & \multirow{5}{*}{0,937} & 0,772 & \multirow{5}{*}{0.748} \\
\hline & ATU2 & & & 0,884 & \\
\hline & ATU3 & & & 0,901 & \\
\hline & ATU4 & & & 0,884 & \\
\hline & ATU5 & & & 0,876 & \\
\hline \multirow{3}{*}{ PBC } & PBC1 & \multirow{3}{*}{0,865} & \multirow{3}{*}{0,908} & 0,830 & \multirow{3}{*}{0.768} \\
\hline & PBC1 & & & 0,877 & \\
\hline & PBC1 & & & 0,919 & \\
\hline \multirow{4}{*}{ SN } & SN1 & \multirow{4}{*}{0,908} & \multirow{4}{*}{0,935} & 0,851 & \multirow{4}{*}{0.782} \\
\hline & SN2 & & & 0,924 & \\
\hline & SN3 & & & 0,882 & \\
\hline & SN4 & & & 0,879 & \\
\hline \multirow{5}{*}{ BI } & BI1 & \multirow{5}{*}{0,943} & \multirow{5}{*}{0,957} & 0,877 & \multirow{5}{*}{0.816} \\
\hline & $\mathrm{BI} 2$ & & & 0,938 & \\
\hline & BI3 & & & 0,931 & \\
\hline & BI4 & & & 0,852 & \\
\hline & BI5 & & & 0,917 & \\
\hline
\end{tabular}


Based on the results obtained in Table 3, the data have passed reliability test with values of Cronbach's Alpha, and Composite Reliability are above 0.6. The data also passed validity tests with values of cross-loadings more than 0.7. All values of AVE also are higher than 0.50. AVE value is 0.50 or higher shows that the latent variable explains more than half of its indicators' variance [34].

PLS-SEM provides parameter estimates that maximize the explained variance $\left(\mathrm{R}^{2}\right.$ values) of the dependent constructs. $\mathrm{R}$ square $\left(\mathrm{R}^{2}\right)$ measures and the level and significance of the path coefficients are the initial evaluation for the structural model. $\mathrm{R}^{2}$ result of 0.20 in some discipline studies such as consumer behavior considered high, $\mathrm{R}^{2}$ values of 0.75 perceived as high in success driver studies. While in marketing studies, $\mathrm{R}^{2}$ values of 0.75 is deemed to be substantial, 0.50 is moderate, and 0.25 is weak [32]. Table 3 shows the value of $\mathrm{R}$ square of two (2) endogenous variables in this study to test the structural model or inner model:

Table 3. Structural Model Test

\begin{tabular}{llc}
\hline & R Square & R Square Adjusted \\
\hline ATU & 0.651 & 0.646 \\
BI & 0.450 & 0.428 \\
\hline
\end{tabular}

Based on Table 3, ATU has an $\mathrm{R}^{2}$ value of 0.651 that shows ATU as an endogenous variable is explained by its exogenous latent variables, namely PU and PEU by $65.1 \%$, and the remaining $34.9 \%$ are explained by other variables outside this study. Then $\mathrm{BI}$ has $\mathrm{R}^{2}$ value of 0.450 shows that $\mathrm{BI}$ as endogenous variables can be explained by its exogenous latent variables, namely ATU, PBC, SN, PU, and PEU of $45 \%$ and the remaining 55\% are explained by other variables outside this study.

Hypothesis Test. After the model indicate robust model, the hypothesis test can be done. The result of the test can be seen in Table 4.

Table 4. Hypothesis Test

\begin{tabular}{|c|c|c|c|c|c|c|}
\hline Hypothesis & Path & $\begin{array}{c}\text { Original } \\
\text { Sample (0) }\end{array}$ & $\begin{array}{c}\text { Standard } \\
\text { Deviation } \\
\text { (STDEV) }\end{array}$ & $\begin{array}{l}\text { T Statistics } \\
\text { (|O/STDEV|) }\end{array}$ & p-value & Result \\
\hline H1 & PU $>$ ATU & 0.278 & 0.087 & 3.201 & 0.001 & Supported \\
\hline $\mathrm{H} 2$ & $\begin{array}{l}\text { PEU -> } \\
\text { ATU }\end{array}$ & 0.605 & 0.079 & 7.674 & 0.000 & Supported \\
\hline H3 & ATU $->B I$ & 0.441 & 0.126 & 3.505 & 0.000 & Supported \\
\hline H4 & $\mathrm{PBC} \rightarrow \mathrm{BI}$ & 0.013 & 0.099 & 0.135 & 0.893 & $\begin{array}{c}\text { Not } \\
\text { Supported }\end{array}$ \\
\hline H5 & $\mathrm{PU} \rightarrow \mathrm{BI}$ & 0.033 & 0.127 & 0.257 & 0.797 & $\begin{array}{c}\text { Not } \\
\text { Supported }\end{array}$ \\
\hline H6 & PEU $->\mathrm{BI}$ & 0.226 & 0.109 & 2.064 & 0.040 & Supported \\
\hline H7 & $\mathrm{SN} \rightarrow>\mathrm{BI}$ & 0.025 & 0.059 & 0.430 & 0.667 & $\begin{array}{c}\text { Not } \\
\text { Supported }\end{array}$ \\
\hline
\end{tabular}




\subsection{Analysis}

\subsubsection{PU Significantly has Positive Effect on ATU}

Perceived Usefulness (PU) has significantly positive effects on Attitude towards Usage (ATU) of waqf fintech. PU has influenced ATU Muslim Indonesia to contribute to cash waqf through fintech. This result study is the same as what TAM proposed. This study also supported by the research done about customer's intention to use fintech services in Taiwan [35].

People tend to use or not use an application to the extent they believe it will help them perform their job better [21]. None will use something if it does not have benefits. If the fintech service makes customers conveniently, efficiently, and quickly obtain relevant information or perform transactions anytime and anywhere, then the customer's positive attitude towards using fintech service will increase [35]. Fintech has benefits and facilitates people to do charity activities like waqf. They no longer need to go to the waqf institutions or meet nazir, just download the waqf applications on their smartphones.

Word "useful" means capable of being used advantageous [21]. Most people will undoubtedly choose the easiest way to do something, the one that does not need significant effort to do. The easiest way to give waqf (cash waqf) is through an online application, either from cellphones or other electronic devices. The benefits of the apps or websites are what make them intend to do cash waqf through fintech instead of traditional (direct) anymore. The higher PU of waqf fintech, the higher ATU of waqf fintech among Indonesian Muslims.

\subsubsection{PEU Significantly has Positive Effect on ATU}

The result of this study is the same as what explained in the TAM theory. Perceived Ease of Use (PEU) has significantly positive effects on Attitude Towards Usage (ATU) of waqf fintech. This study also supported by the research about Muslim student's intention in using cash waqf mobile application called NU BTN [23]. Another research finding also explains about Taiwan's consumer behavioral intentions in using Fintech Service [35]. In TAM theory, PEU and ATU have close relationships and empirically have verification in some IT literature [23].

Word "ease" defined as there is no difficulty or no need for great effort [21]. The ease of use of a system will undoubtedly affect one's attitude toward the system. This is especially applies in the use of a technology system. If an application or website is considered too difficult to use, it will undoubtedly make people reluctant to use it. People will tend to choose something easy to use, no need to spend a lot of time understanding the steps to use an application. If the fintech service is easy to use, the application is friendly and easy to download; this apps will affect customer's ATU fintech service [35]. Although a system is certainly useful, people will tend not to use it if not easy to use [21]. The higher PEU of waqf fintech, the higher ATU of waqf fintech.

The existing waqf applications or websites believed easy to use by Indonesian Muslims. Indeed, most apps currently available in smartphones provide natural ways to be used. Besides, steps of the use of the apps for the first users even help them more easily understand the apps. And also nowadays many YouTubers, vloggers, or other social media users often make a tutorial about steps about how to use some apps that can help new users to understand easily. 


\subsubsection{ATU Significantly has Positive Effect on BI}

Attitude Towards Usage (ATU) has significantly positive to Behavioral Intention (BI) of using waqf fintech. This result has the same statement as in TAM theory. This study also supported by the research done by about student's intention to do cash waqf, Muslim student's intention to contribute cash waqf through NU BTN Mobile application, and consumer's intentions in using fintech service in Taiwan [36] [23] [35].

A person's attitude relates to other people, physical objects, behavior, or policies, while behavior is one or more actions that can be observed by individuals [35]. Assumed that attitude was the key to understanding human behaviour, and changes in attitudes would influence the reactions [36]. The degree of positive and negative evaluation that forms an attitude of customer in using fintech service is the most important determinant that affects customers to use or not use fintech service. The general idea of consistency is usually used to predict behavior from attitude [35] [37].

When someone has a positive attitude towards using fintech waqf, then the intention to use it will arise. When BI occurs, it is likely that the behavior of using fintech waqf to do cash waqf will likely be more significant. The higher ATU of waqf fintech, the higher BI of using waqf fintech among Indonesian Muslims.

\subsubsection{PBC has no Effect on BI}

Perceived Behavioral Control (PBC) has no significant to Behavioral Intention (BI) of paying waqf through fintech. This is opposite to the TPB theory that stated PBC has positive effects on BI [18] [38].

The perceived behavioral control describes the people's perception of having resources and abilities to do something, in this case, is to do cash waqf through fintech. Ability to pay waqf through fintech be achieved when resources are available such as the internet, smartphone or computer, and skill). Meanwhile, the conditions that people know and can use fintech to pay waqf are not making them willing to do it.

The reason that can elaborate from this finding is because the lack of awareness to do waqf. Otherwise, technology can make people more wasteful, and there is evidence of high number of online purchasing nowadays. Another reason is that people cannot feel the urgency and benefit for their personal to pay waqf through fintech. Even though people can use fintech to donate some waqf funds, but they need time to deep thinking and make a decision. Cash waqf behavior is unique due to voluntary and based on trust [39]. Because trust is an essential thing in voluntary activities, so that waqf institutions need to have good transparency and accountability.

\subsubsection{PU has no Effect on BI}

Perceived Usefulness (PU) does not have a significant impact on Behavioral Intention (BI) to use fintech for waqf. This finding is different from previous research conducted showed that the usefulness influences intention of using Bitcoin [26]. Otherwise, security factors and comfortability have a low relationship with the intention. People think about how waqf funds operated and distributed; people cannot give waqf without any knowledge about the waqf institution.

Perceived usefulness is generally understood to mean people's trust level that usage of technology can increase performance. In this case, PU describes trust of someone in using 
fintech to pay waqf can improve their performance. Fintech is a technology that covers all sectors and market segments in this digital era. For example, nowadays the children use Gojek and pay it with Gopay in daily activities, such as for going to school, buying food, etc. In this digital era, people can learn and adopt technology as fast as they read the manual guide or use it directly.

However, the usefulness to pay waqf through fintech with easy way cannot directly make people do that thing. Indonesia has a big potential of waqf, especially cash waqf. Technology can collect more waqf funds across time and place. Unfortunately, most Indonesian Muslim still has a traditional mindset that waqf is only about land, graves, mosque, and school. In this contemporary world, cash waqf is more effective and can generate income then give more benefits for beneficiaries.

\subsubsection{PEU Significantly has Positive Effect on BI}

Perceived Ease of Use (PEU) has significantly positive effects on Behavioral Intention (BI) of using waqf fintech. This result indicates the same statement, as TAM stated. This study supported the research about Muslim student's intention to contribute cash waqf through NU BTN Mobile application [23].

PEU is one of the determinants of someone's intention to do behavior. PEU can affect both ATU and also BI. When someone thinks a system or application is easy to use, he/she can immediately try it. If he/she feels that the system or apps is suitable for needs, he/she will continue to use it or otherwise stop using it. Many applications are free, so trying a new application will not make any disadvantages.

When the user feels that fintech waqf is not challenging to use and gives a positive attitude towards it, there will be an intention to use fintech. Instead of going directly to a waqf institution, it is better to go online that doesn't need much energy and costs less. The higher a person feels that fintech waqf is easy to use, the higher the BI level of fintech waqf usage. BI is a factor influencing the realization of a behavior. So, he higher BI of using waqf fintech, the higher Muslim to choose waqf fintech as media to do cash waqf.

\subsubsection{SN has no Effect on BI}

Subjective Norm (SN) significantly has no effect on Behavioral Intention (BI) of using fintech to pay waqf. The finding of this study consistently the same as previous studies about Muslim's intention of giving cash waqf [39]. However, this study has different result with previous research that showed positive significant impact of SN on intention to use mobilebased payment and positive effect on BI in investigating the determinant of student's intention to do cash waqf [25][36].

Subjective norm refers to social pressure that felt by someone either to pay waqf through fintech or not. Fintech provides fundamental shifting in this digital era through all sectors include Islamic social finance such as waqf. This shifting can be successful when people have literacy with sufficient resources, for example, education, socialization, and suggestions from their environment. According to this study, subjective norm has no impact on behavioral intention for people to use fintech to give waqf.

Waqf is well known a long time ago in Islamic historical background. Waqf development is dynamic as such as technology. Knowledge and awareness factor has a key role in waqf development. However, waqf awareness is not as high as technology among Indonesian Muslims. People know many fintech platforms, but they do not realize that waqf can be done 
through fintech. Because of lack of awareness and education about waqf so that people cannot influence others to do waqf too. People do not have the confidence to act waqf and suggest others do the same thing.

Since those problems are the priority to be solved, the integration of all stakeholders such as the Indonesian Waqf Board (BWI), Financial Service Authority (OJK), Ministry of Religious Affairs, Waqf Institutions, and others needed to synergize waqf literacy and campaign among Indonesian Muslims. This movement has purpose of increasing Muslim's intention and awareness. Also, the government needs to arrange sufficient regulation to secure this waqf fund and people's trust, mainly collected through fintech. Creating professional nazir and fintech developers is also important to face this digital era. The main problems to develop Islamic fintech are lack of policy and human resources [27].

\section{Conclusion and Recommendation}

\subsection{Conclusion}

This article investigates what are determinants of Indonesian Muslims to do cash waqf through fintech are. The findings of this study explained that PEU and PU statistically have a significant effect on ATU. Then, PU, ATU, PEU have a significant impact on BI. Otherwise, PBC, PU, and SN have no significant influence BI. This study also finds that literacy of fintechbased waqf is still limited. Even though people tend to use fintech in daily activities, but it is for commercial purposes only. There is significant potential to encourage social purposes through fintech, since people use internet every day to get information. Furthermore, this study also gives following recommendations for academic purpose, policy and practice.

\subsection{Recommendation}

\subsubsection{Implication for academic}

Fintech is a new emerging market in this global era. Research that focuses on fintech is still limited. This research tries to get more issues in the social areas that can be done by fintech, especially in cash waqf potential. Therefore, technology can give more social impact and humanity. However, this study has limitations such as the number of respondents and variables used in this research. Further studies can use more respondents and classify them based on Islamic or general education. Religiosity, trust, and corporate governance also can be added to the next research. Knowledge about waqf also can be moderating variable, such as a study that use knowledge about riba to see intention of using e-money [40].

\subsubsection{Implication for regulators}

The insight of this study might strengthen the role of stakeholders in arranging policy and regulation, the process of decision making how to encourage the fintech sector for philanthropy purpose, especially in making cash waqf funds. Issues that should be highlight are about waqf literacy and education for public, security and waqf governance, and supporting system for professional human resources such as giving scholarships in developing fintech, creating further 
waqf scholars, etc. Policy and regulation are needed to provide security of waqf funds from money laundry, terrorism, or other fraud activities.

\subsubsection{Implication for waqf institutions}

Based on some previous researches, lack of professional nazir and creativity is one of the issues facing waqf development, because nazir is the key role of productive waqf [41] [42] [43]. Nowadays, nazir should have management skills such as socio-entrepreneur to make waqf more productive, and then it will make the public know how significant the benefit of waqf is. Human resource development can be improved by synergizing and integrating main goal of waqf for maslahah from all stakeholders. Waqf is a unique sector since it is voluntary-based activities, and trust is the primary factor for this sector. Maintaining trust from the public can be done by accountability and transparency of waqf institutions by giving report [44]. Fintech can make waqf institution more transparent by giving a real time report on their platform. This condition might affect the public to know more about waqf and increase their intention.

\section{Acknowledgment}

Authors would like to thank for Directorate of Research and Community Service of Universitas Indonesia for giving financial support for this research through PITMA B Grant Research Program.

\section{References}

[1] Thomson Reuters \& DinarStandard. (2018). State of The Global Islamic Economy Report 2018/19

[2] Al-Khatib Al-Sharbini. The Book of Endowment (Kitab al-Waqf) from Mughni al-Muhtaj ila

Ma'rifat Ma'ani Alfaz al-Minhaj. Translated with an introduction, appendices and notes by Nicholas Mahdi Lock. ISBN 978-967-0149-58-5 (2015).

[3] Pew Research Center. The Future of the Global Muslim Population, Projections for 2010-2030.

(2011).

[4] Nafis, Cholil. Aplikasi Wakaf Uang di Indonesia. (2012).

[5] Syafiq, A. Pemanfaatan Dana Wakaf Tunai untuk Pembiayaan Pembangunan

Infrastruktur. Ziswaf: Jurnal Zakat dan Wakaf, 4(1), 25-40 (2018).

[6] World Giving Index. (2018).

[7] We Are Social. (2019).

[8] McKinsey \& Company. Unlocking Indonesia's Digital Opportunity, (2016).

[9] Kasali, Rhenald. Disruption. Jakarta: PT Gramedi Pustaka Utama (2017).

[10] Mention, L., and Anne. The Future of Fintech. Research-Technology Management, 62(4), 5963(2019).

[11] Romanova, I. \& Kudinska, M. Banking and Fintech: Challange or Opportunity?. Contemporary Studies in Economic and Financial Analysis, 98, 21-35(2016).

[12] Ryandono, M.N.H. FinTech Waqaf: Solusi Permodalan Perusahaan Startup Wirausaha Muda. Jurnal Studi Pemuda, 7(2), 111-121 (2018).

[13] Yusof, M., Hasanudin, M.H., \& Romlin, N. Cash Waqf and Infaq: A Proposed E-Philanthropy in Malaysia. Jurnal Kemanusiaan, 22,(1)1-10 (2017).

[14] Zeni, N.A.M. Developing a Holistic Business Model for Efficient Waqf Property in Malaysia. Global Business and Management Research: An International Journal, 10(3), 1092-1106 (2018).

[15] Sulaiman, S., Hasan., \& Noordin. Proposed Models For Unit Trust Waqf and The Parameters for Theirs Applications. International Journal of Islamic Finance (ISRA), 11(1), 62-81 (2019). 
[16] Haron, M., Kamarudin, M.K., Fauzi, N.A., Arif, M.M., and Zainudin, M.M. Cash Waqf Collection: Any Potential Factors To Influence it?. International Journal of Business, Economics and Law, 9 (2), 27-33 (2016).

[17] Sukamto. Menuju Era Baru Wakaf Tunai; Inovasi Finansial Islam dalam Mensejahterakan Umat. Jurnal Ekonomi Islam, 9(2), 193-212 (2018).

[18] Ajzen, I. The Theory of Planned Behavior. Organizational behavior and human decision processes, 50(2), 179-211 (1991).

[19] Satsios, Nikolaos \& Hadjidakis, Spyros. Applying the Theory of Planned Behaviour (TPB) in Saving Behaviour of Pomak Housholds. International Journal of Finance Research, 9(2), 122133(2018).

[20] Surendran,P. Technology Accaptance Model: A Survey of Literature. International Journal of Business and Social Research, 2(4), 175-178 (2012).

[21] Davis, F. D. Perceived Usefulness, Perceived Ease of Use, and User Acceptance of Information Technology. Management Information Systems Research Center, 13(3), 319-340 (1989).

[22] Sakti, M.R.P., Thaker, H.,Qoyum, A., \& Qizam, A. Determinants of Cash Waqf Contribution in Klang Valley and Selangor: A SEM Approach. Journal of Islamic Monetary Economics and Finance, 2(1), 111-144, e-ISSN: 24460-6618 (2016).

[23] Dennis, D., Qoyum, A., and Sakti, M.R. Determinant of Cash Waqf Nahdatul Ulama (case of Muslim Students in Indonesia). Madania, 22(1), 19-32 (2018).

[24] Shukkor, S.A., Shukor, S.A., Ibrahim, P., \& Hussin, M.F. Trust on Awqaf Institutions: Evidence from Malaysia. Journal of Islamic Marketing, (10)2, pp. 511-524 (2019).

[25] Kim, Y., Park, Y.J., Choi, J., \& Yeon, J. The Adoption of Mobile Payment Service for "Fintech". International Journal of Applied Engineering Research, 11 (2), 1058-1061 (2016).

[26] Won-jun, Lee. Understanding Consumer Acceptance of Fintech Service: An Extensions of the TAM Model to Understand Bitcoin. Journal of Business and Management, 20(7), 34-37 (2018).

[27] Rusydiana, A. S. Developing Islamic financial technology in Indonesia. Hasanuddin Economics and Business Review, 2(2), 143-152 (2018).

[28] Hair J.F., Sarstedt, M., Hopkins, L., \& G. Kuppelwieser, V. Partial least squares structural equation modeling (PLS-SEM) An emerging tool in business research. European Business Review, 26(2), 106121 (2014).

[29] Hair, J. F., Sarstedt, M., Pieper, T. M., \& Ringle, C. M. The use of partial least squares structural equation modeling in strategic management research: a review of past practices and recommendations for future applications. Long range planning, 45(5-6), 320-340 (2012).

[30] Haneef, M.A.M, Kamil, N, Ayuniyyah, Q. Development of Waqf in Indonesia: The SWOT Analysis of Indonesia Waqf Board (BWI). Al-Infaq: Jurnal Ekonomi Islam, 8(2), 136-150, e-ISSN: 2579-6453 (2017).

[31] Khairunisa, R., Akbar, N., Devi, AEnhance Islamic Banking's Role to Raise Cash Waqf Funds. Iqtishadia, 10(2), 1-28 . (2017).

[32] Ali, K. M., et al. (eds.). Revitalization of Waqf for Socio-Economic Development, Volume II (2019).

[33] Setia, A. Reintegrating the Legal into the Social: Reviving Islamic Transactional Law in the Context to the Civil Economy, with Special Reference to Waqf. Law and Development Review, 11(1), 209-250 . (2018).

[34] Hair, J. F., Christian M. Ringle \& Marko Sarstedt . PLS-SEM: Indeed a Silver Bullet, Journal of Marketing Theory and Practice, 19:2, 139-152 (2011).

[35] Chuang, L. M., Liu, C. C., \& Kao, H. K. The Adoption of Fintech Service: TAM Perspective. International Journal of Management and Administrative Science (IJMAS), 3(7), 1-15 (2016).

[36] Fathurrahman, R. M. S., \& Maulana, H. Factors that Influence Students'awareness in Participating of Cash Waqf. Islamic Business and Management Journal, 1(2), 47-56 (2018).

[37] Ajzen, I., \& Fishbein, M. Attitude-behavior relations: A theoretical analysis and review of empirical research. Psychological bulletin, 84(5), 888 (1977).

[38] Ajzen, I., \& Fishbein, M. The influence of attitudes on behavior. The handbook of attitudes, 173(221) (2018). 
[39] Osman, A. F., Mohammed, M. O., \& Fadzil, A. Factor influencing cash Waqf giving behavior: A revised theory of planned behavior. Journal of Global Business and Social Entrepreneurship, 1(2), 1225(2016)

[40] Aji, H.M., Muafi, Berakon. I., Kholid, M.N. (2019). The Moderating Role of Knowledge about Riba on Intention to Use E-Money: Findings from Indonesia. $6^{\text {th }}$ International Conference on Industrial Engineering and Applications, 588-593(2019).

[41] Hasymi, Sherafat Ali. Management of Waqf: Past and Present, dalam Hasmat Basyar (ed.). Management and Development of Auqaf Properties. Jeddah: Islamic Research and Training Institute and Islamic Development Bank (1987).

[42] Fadilah, S. Going Concern: An Implementation in Waqf Institutions (Religious Charitable Endowment). Procedia-Social and Behavioral Sciences, 211, 356-363 (2015).

[43] Huda, N., Rini, N., Mardoni, Y., Hudori, K., \& Anggraini, D. Problems, Solutions and Strategies Priority for Waqf in Indonesia. Journal of Economic Cooperation \& Development, 38(1) (2017).

[44] Yaacob, H., Petra., S., Sumardi., A., \& Nahar, H.S. Accountability through Accounting and Reporting Lenses: Lessons from an Awqaf Institution in a Southeast Asia Country. Humanomics, 31(3), 299-313 (2015). 